\title{
ACTIVATION OF B-CATENIN SIGNALLING LEADS TO TEMPOROMANDIBULAR JOINT DEFECTS
}

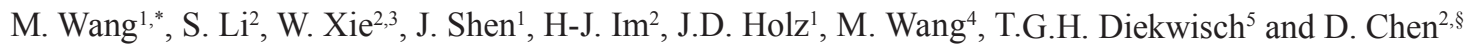 \\ ${ }^{1}$ Department of Orthopaedics, Center for Musculoskeletal Research, University of Rochester Medical Center, \\ Rochester, NY 14642, USA \\ ${ }^{2}$ Department of Biochemistry, Rush University Medical Center, Chicago, IL 60612, USA \\ ${ }^{3}$ Liaoning University of Traditional Chinese Medicine, Liaoning 110847, China \\ ${ }^{4}$ Department of Oral Anatomy and Physiology and TMD, College of Stomatology, Fourth Military Medical \\ University, Xi'an 710032, China \\ ${ }^{5}$ Department of Oral Biology, University of Illinois at Chicago College of Dentistry, Chicago, IL 60612, USA
}

*Current address: Section of Endocrinology, Department of Internal Medicine, Yale University, New Haven, CT 06520, USA

\begin{abstract}
Despite extensive research in knee and hip osteoarthritis (OA), the underlying mechanism of temporomandibular joint (TMJ) disorder remains largely unknown. The purpose of this study was to determine whether the constitutive activation of $\beta$-catenin in the middle and deep layers of the articular cartilage can compromise the homeostasis of this tissue in the TMJ. Col2CreER ${ }^{T 2}$ transgenic mice were bred with $R_{o s a^{m T / m G}}$ reporter mice to determine Cre recombination efficiency. Col2CreER ${ }^{T 2}$ mice were then crossed with $\beta$-catenin ${ }^{\text {fox }(\text { ex } 3) /+}$ mice to generate $\beta$-catenin conditional activation mice, $\beta$-catenin (ex3) ${ }^{\text {COILER }}$. TMJ samples were harvested when the mice were 1-, 3- or 6-month-old and evaluated using histology, histomorphometry and immunohistochemistry. $\beta$-catenin $(\text { ex3 })^{\text {Col2ER }}$ mice were further crossed with Mmp1 $3^{\text {fox } x \text { fox }}$ and Adamts $5^{--}$mice to generate $(\beta$-catenin (ex3)/Mmp13) CollER and $\beta$-catenin (ex3) Col2ER)/Adamts $5^{-/}$double mutant mice to investigate the role of Mmp13 and Adamts 5 in the development of TMJ disorder. High levels of Cre-recombination were seen in Col2CreER ${ }^{T 2} ; \operatorname{Ros}^{m T / m G}$ mice. Progressive TMJ defects developed in 1-, 3- and 6-month-old $\beta$-catenin (ex3) ColzER mice, as revealed by histology and histomorphometry. Results further demonstrated that the defects observed in $\beta$-catenin $(\text { ex } 3)^{\text {COILER }}$ mice were significantly decelerated after deletion of the Mmp13 or Adamts 5 gene in $\left(\beta\right.$-catenin (ex3)/Mmp13) Col2ER or $\beta$-catenin $(\text { ex3 })^{\text {Col2ER/ }}$ Adamts $5^{\circ}$ double mutant mice. In summary, we found that $\beta$-catenin is a critical gene in the induction of TMJ cartilage degeneration, and over-expressing $\beta$-catenin in TMJ cartilage leads to defects assembling an OAlike phenotype. Deletion of Mmp13 and Adamts 5 in $\beta$-catenin $(\text { ex } 3)^{\text {Col2ER }}$ mice ameliorates the development of TMJ defects. This study suggests that Mmp13 and Adamts 5 could be potential therapeutic targets for the treatment of TMJ disorders.
\end{abstract}

Keywords: Temporomandibular joint, osteoarthritis, $\beta$-catenin, MMP13, Adamts5.

$\S$ Address for correspondence:

Di Chen, MD, PhD

Department of Biochemistry

Rush University Medical Center

1735 West Harrison Street
Cohn Research Building, Suite 508

Chicago, IL 60612, USA

Telephone Number: 1-312-942-5702

FAX Number: 1-312-942-3053

E-mail: di_chen@rush.edu

\section{Introduction}

The temporomandibular joint (TMJ) is a hinge and gliding joint that connects the condyle of the mandibular bone with the temporal articular surface composed of a concave, socket-like articular fossa and a convex eminence. Similar to the knee joint, the temporal bone and the condyle are separated and cushioned by an articular disc (Fig. 1A). The TMJ disc separates the joint space into two distinct parts. The superior joint space is bounded by the articular fossa and the articular eminence. The inferior joint space is bounded by the condyle. TMJ is one of the most frequently used joints in the human body. It is reported that about $40-70 \%$ American adults have at least one sign of TMJ disorders and at least $33 \%$ among those have one symptom, such as pain, limited mandibular motion, and TMJ sounds (Scrivani et al., 2008). The American Academy of Orofacial Pain classified TMJ disorder into different subtypes (de Leeuw, 2008). Among these subgroups, TMJ osteoarthritis $(\mathrm{OA})$ is a highly prevalent degenerative disease that affects articular cartilage during pathological conditions, as well as during the aging process. Currently, rest therapy, pain relief, and thermotherapy are the principal clinical treatment methods, and there is no preventative treatment. Moreover, current knowledge of TMJ OA is derived primarily from clinical investigations, and many aspects of TMJ OA, especially the underlying molecular mechanisms, remain largely under-studied (Rando and Waldron, 2012).

Jaw function and movement result in continuous and ever changing mechanical loads exerted on the TMJ, which in turn affect the morphology and composition of its cartilages (Iwasaki et al., 2010). TMJ condylar articular cartilage is an avascular, compressible tissue comprised of dense extracellular collagen fibres and proteoglycans that protect the joint from damage during mechanical loading. The collagen fibres are well organised and aligned in an antero-posterior orientation to optimise resistance to shear stress (Singh and Detamore, 2008). Morphologically, 
A

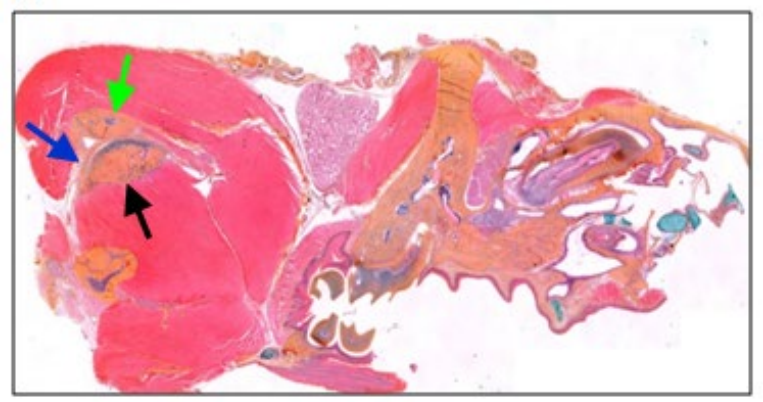

B

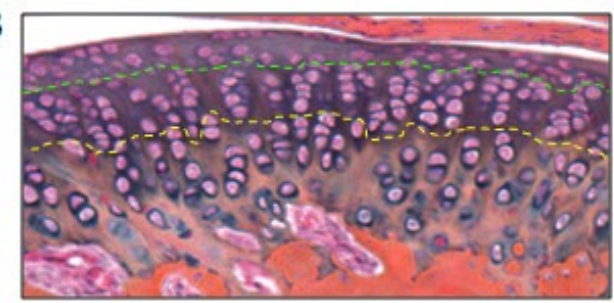

C
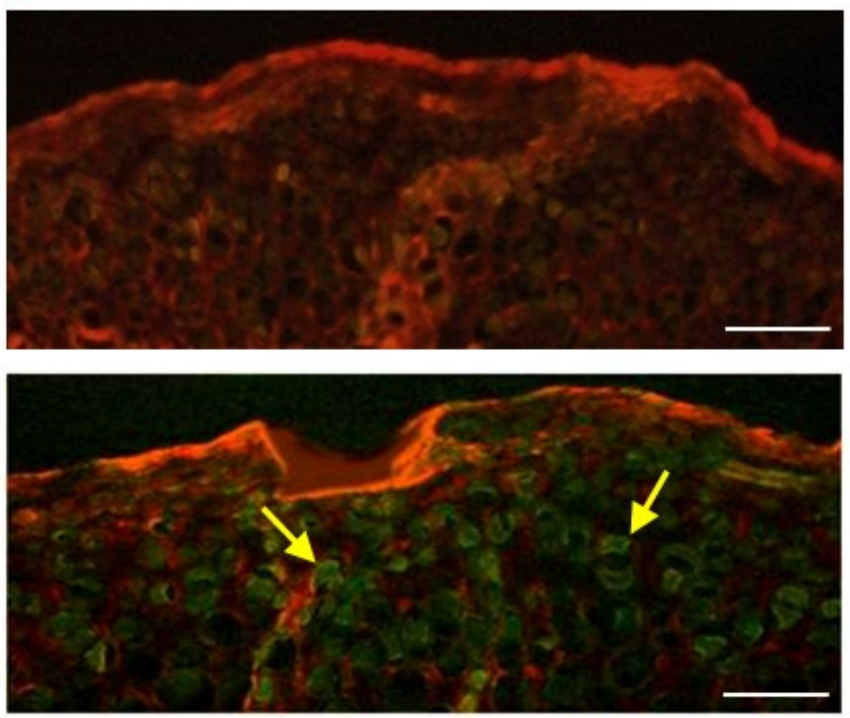

Scale bar $=50 \mu \mathrm{m}$
D

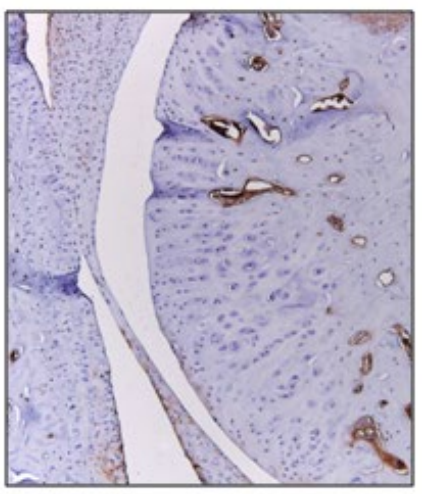

Cre-negative

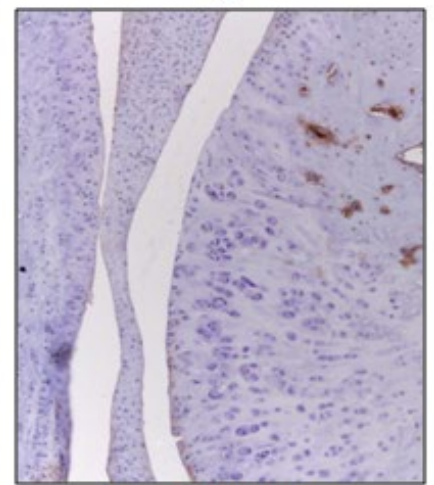

$\beta$-catenin, IHC $\beta$-catenin $(e \times 3)^{\text {Col2ER }}$

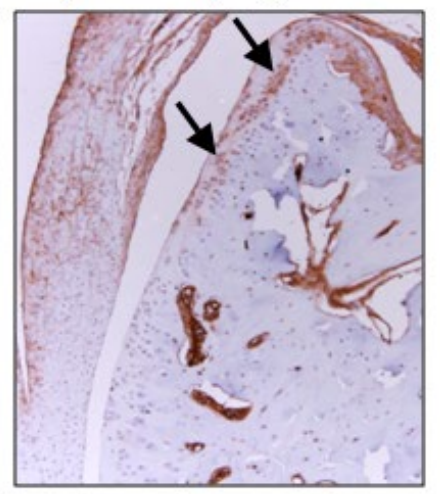

Fig. 1. Col2CreER $R^{T 2}$ mice efficiently target TMJ cartilage tissue. (A) Alcian blue/H\&E stained sagittal skull section of adult wild-type mouse. The temporal bone (green arrow) and the mandible condyle (black arrow) are separated by an articular disc (blue arrow). TMJ condylar cartilage was stained with Alcian blue. (B) Normal TMJ cartilage can be divided into three layers: superficial layer (above green dashed line), middle layer (between green and yellow dashed lines), and deep layer (below yellow dashed line). (C) Col2CreER ${ }^{T 2}$ mice were bred with $\operatorname{Rosa}^{m T / m G}$ reporter mice. Tamoxifen was administered when the mice were 2-week-old $(0.1 \mathrm{mg} / \mathrm{g}$ body weight, i.p., daily for $5 \mathrm{~d})$. TMJ samples were harvested at 4-week-old. Fluorescent images showed red mT labelling in Cre-negative control mouse (upper panel) and green $\mathrm{mG}$ labelled chondrocytes in Cre-positive mouse (yellow arrows) (lower panel). (D) $\beta$-catenin IHC was performed and the result showed that $\beta$-catenin expression was up-regulated in the TMJ tissue of $\beta$-catenin $(\text { ex3 })^{\text {Col2ER }}$ mice.

the condylar cartilage is divided into the superficial, middle, and deep layers (Fig. 1B) (Luder et al., 1988; Mizoguchi et al., 1996). Above the middle layer the tissue is fibrocartilage-like and beneath the middle layer is hyaline-like (Kuroda et al. 2009). The principal component of the superficial layer is type I collagen (Col1), and the principal component of the middle and deep layer is type II collagen (Col2) (Hirschmann and Shuttleworth, 1976). Mandibular condylar articular chondrocytes are the only cell type embedded in TMJ cartilage, and their function includes maintenance of the cartilaginous matrix.

The pathological progression of TMJ OA parallels that of knee and hip OA and is considered to be a similar disease (Kuroda et al., 2009; de Bont et al., 1993). During the initiation stage of TMJ OA, the cartilage surface remains intact. At the cellular level, articular chondrocytes with low metabolism undergo hypertrophy, followed by apoptosis. These cellular effects result in cartilage fibrillation and subsequent progressive cartilage loss at the tissue level. Subchondral bone sclerosis and osteophyte formation happen in late-stage OA (Wang et al., 2011). At the molecular level, primary cartilage matrix proteins, such as Col2 and aggrecan, start to decrease, concomitant with gradual increases in the expression of marker genes of chondrocyte hypertrophy, such as Runx2 and Col10, as well as the genes coding for primary enzymes responsible for cartilage degeneration, such as 
Mmp13, Adamts4 and Adamts5 (Neuhold et al., 2001). Decreasing anabolic components, increasing metabolic components and proteolytic enzymes in the cartilage eventually tip the balance away from matrix maintenance toward degradation, resulting in complete cartilage erosion over time.

$\beta$-catenin is a key molecule in the canonical Wnt signalling pathway, which plays a critical role in bone, cartilage and joint formation, and development (Yang, $2003)$. Dysregulation of $\beta$-catenin causes cartilage degeneration and OA. In previous studies, we have reported that $\beta$-catenin expression was significantly up-regulated in articular cartilage in patients with knee OA (Zhu et $a l ., 2009)$ and in the intervertebral disc (IVD) tissues from patients with IVD degeneration (Wang et al., 2012). Furthermore, Col2-CreER ${ }^{T 2}$ driven cartilage-specific $\beta$-catenin overexpression in both knee joint and the IVD tissue leads to progressive cartilage loss and a degenerative phenotype in this mouse model (Zhu et al., 2009; Wang et $a l ., 2012)$. These findings suggest that $\beta$-catenin is a critical molecule in OA pathogenesis. MMP13 and Adamts5 are key enzymes that target collagens and aggrecans for proteolytic degradation in cartilage (Glasson et al., 2005; Knäuper et al., 1996; Reboul et al., 1996; Roach et al., 2005; Wang et al., 2012, 2013). In the present study, we investigated whether the constitutive activation of $\beta$-catenin in the middle and deep layers of the articular cartilage can compromise the homeostasis of this tissue in the TMJ using a $\beta$-catenin (ex3) Col2ER mouse model.

\section{Materials and Methods}

\section{Animals}

Rosa $^{m T / m G}$ reporter mice, Mmp $13^{\text {floxfflox }}$ mice, and Adamts $5^{-1-}$ mice were obtained from Jackson Laboratories (Bar Harbor, ME, USA) (Muzumdar et al., 2007; Stickens et al., 2004; McCulloch et al., 2009a, 2009b). Col2CreER ${ }^{T 2}$ transgenic mice were generated as previously described (Chen et al., 2007; Zhu et al., 2008; Jin et al., 2011; Wang et al., 2012; 2013). $\beta$-catenin (ex3) flox/flox mice were originally reported by Harada et al. (1999), and we have used these mice in our previous studies (Zhu et al., 2009; Wang et al., 2012, 2014). $\beta$-catenin (ex3) Col2ER mice, $(\beta$-catenin (ex3)/Mmp13) Col2ER and $\beta$-catenin (ex3) Col2ER/Adamts $5^{-/}$double mutant mice, and their Cre-negative littermate control mice were generated as shown in Tables 1-3. Tamoxifen (Sigma, St. Louis, MO, USA) was administered into 2-week-old mice by intraperitoneal (i.p.) injection $(1 \mathrm{mg} / 10 \mathrm{~g}$ body weight for $5 \mathrm{~d}), n=5$ in each group. Animal protocols were approved by the IACUC of the University of Rochester.

\section{Histology and histomorphometry}

We dissected skulls from $\beta$-catenin $(\text { ex } 3)^{\text {Col2ER }}$ mice, $(\beta$-catenin(ex3)/Mmp13) Col2ER mice, $\beta$ - catenin $($ ex3) Col2ER/Adamts $5^{-/-}$mice and their corresponding Crenegative control mice. Samples were fixed in $10 \%$ neutral buffered formalin (VWR, Radnor, PA, USA) for $3 \mathrm{~d}$, then decalcified with formic acid (Decal Chemical Corp., Suffern, NY, USA) for $7 \mathrm{~d}$. After neutralising with

Table 1. Breeding and production of $\beta$-catenin $(\text { ex } 3)^{\text {Col2ER }}$ mice.

\begin{tabular}{|c|c|}
\hline Breeding & Desired progeny \\
\hline a) $\beta$-catenin $(\text { ex } 3)^{f o x /+} \times \beta$-catenin $(\operatorname{ex} 3)^{\text {fox } x++}$ & $\beta$-catenin $(\text { ex3 })^{\text {foxtflox }}$ \\
\hline b) $\operatorname{Col} 2 \operatorname{CreER}^{T 2} \mathrm{x} \beta$-catenin $(\operatorname{ex} 3)^{\text {flox } x \text { flox }}$ & $\beta$-catenin $(\text { ex } 3)^{\text {Col2ER }}$ and $\beta$-catenin $(\text { ex } 3)^{f o x /+}$ \\
\hline
\end{tabular}

Table 2. Breeding and production of $(\beta \text {-catenin }(\text { ex3 }) / M m p 13)^{\text {Col2ER }}$ mice.

\begin{tabular}{|c|c|}
\hline Breeding & Desired progeny \\
\hline a) $\mathrm{Col}_{2} \mathrm{CreER}^{T 2} \mathrm{x} \mathrm{Mmp} 13^{\text {fox } f f l o x}$ & Col2CreER $R^{T 2} ; \mathrm{Mmp}_{1} 3^{\text {flox/+}}$ \\
\hline b) $\operatorname{Col} 2 \mathrm{CreER} R^{T 2} ; \mathrm{Mmp} 13^{\text {fox } /+}$ x $\mathrm{Mmp} 13^{\text {fox } x / f o x}$ & Mmp13 $3^{\text {Col2ER }}$ \\
\hline c) $M m p 13^{\text {foxfflox }} \mathrm{x} \beta$-catenin $(\text { ex3 })^{\text {flox } f f l o x}$ & $\beta$-catenin $(\operatorname{ex3})^{f t o x /+} ; M m p 13^{f t o x /+}$ \\
\hline $\begin{array}{l}\text { d) } \beta \text {-catenin }(\operatorname{ex} 3)^{f o x /+} ; M m p 13^{f o x /+} \mathrm{x} \\
\beta \text {-catenin }(\operatorname{ex} 3)^{\text {fox } /+} ; \operatorname{Mmp} 13^{\text {fox } /+}\end{array}$ & $\beta$-catenin $(\text { ex } 3)^{f l o x} / f \circ x ; M m p 13^{f o x} ; f f o x$ \\
\hline 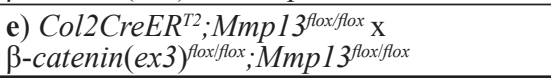 & $\begin{array}{l}(\beta \text {-catenin }(\text { ex3 }) / M m p 13)^{\text {Coll2ER }} \\
\text { and } \beta \text {-catenin }(\text { ex3 })^{\text {flox/++}} ; M m p 13^{\text {fox } f \text { flox }}\end{array}$ \\
\hline
\end{tabular}

Table 3. Breeding and production of $\beta$-catenin $(\text { ex3 })^{\text {Col2ER } / \text { Adamts } 5^{-/} \text {mice. }}$

\begin{tabular}{|c|c|}
\hline Breeding & Desired progeny \\
\hline a) $\operatorname{Col} 2 \mathrm{CreER}^{T 2} \mathrm{x}$ Adamts5 $5^{-/}$ & Col2CreER $^{T 2} ;$ Adamts $^{+/-}$ \\
\hline b) $C o l 2 \mathrm{CreER}^{T 2}$; Adamts5 ${ }^{+/}$x Adamts $5^{-/-}$ & Col2CreER $^{T 2}$; Adamts5 ${ }^{-/-}$ \\
\hline c) Adamts $5^{-/} \times \beta$-catenin $(\operatorname{ex3})^{\text {flox/flox }}$ & $\beta$-catenin $(\text { ex3 })^{\text {flox } /+} ;$ Adamts $5^{+/-}$ \\
\hline $\begin{array}{l}\text { d) } \beta \text {-catenin }(\text { ex } 3)^{\text {flox } /+} ; \text { Adamts }^{+/-} \mathrm{x} \\
\beta \text {-catenin }(\text { ex } 3)^{\text {flox/++}} ; \text { Adamts }^{+/-}\end{array}$ & $\beta$-catenin $(\text { ex3 })^{\text {floxfflox }} ;$ Adamts $5^{-/}$ \\
\hline $\begin{array}{l}\text { e) } \operatorname{Col} 2 C_{\text {CreER }}{ }^{T 2} ; \text { Adamts }^{-/} \mathrm{x} \\
\beta \text {-catenin }(\text { ex3 })^{\text {floxiflox }} ; \text { Adamts5 } 5^{-/}\end{array}$ & $\begin{array}{l}\beta \text {-catenin }(\text { ex } 3)^{\text {Col2ER }} / \text { Adamts } 5^{-/-} \\
\text {and } \beta \text {-catenin }(\text { ex3 })^{\text {flox/+}} / \text { Adamts } 5^{-/-}\end{array}$ \\
\hline
\end{tabular}


Cal-arrest (Decal Chemical Corp., Suffern, NY, USA), samples were processed and embedded in paraffin. Three $\mu \mathrm{m}$ thick mid-sagittal sections at 3 different levels (50 $\mu \mathrm{m}$ apart) were cut from the medial compartment of the TMJ. The sections were stained with Alcian blue/H\&E (AB/ $\mathrm{H} \& \mathrm{E})$ and Safranin $\mathrm{O} /$ Fast green (SO/FG). Quantitative histomorphometric measurement, using ImagePro 4.5 (Leeds Precision Instruments, Minneapolis, MN, USA), was used to collect data. Alcian blue-positive staining areas were outlined on projected images of each histologic section to determine articular cartilage area and thickness. Three slides per mouse, 5 mice per group were analysed in the experiment.

\section{Microcomputed tomography $(\boldsymbol{\mu C T})$}

Prior to histological processing, we evaluated formalinfixed TMJ tissues by $\mu \mathrm{CT}$. We used a Scanco vivaCT40 cone-beam scanner (SCANCO Medical, Brüttisellen, Switzerland) with $55 \mathrm{kVp}$ source and $142 \mu \mathrm{A}$ current. We scanned the TMJ tissues at a resolution of $10.5 \mathrm{~mm}$. The scanned images from each group were evaluated at the same thresholds to allow 3-dimensional structural rendering of each sample.

\section{Cre-recombination efficiency}

$\operatorname{Rosa}^{m T / m G}$ (membrane-Tomato/membrane-Green) mice contain two loxP sites on either side of the mT cassette. Mice express red fluorescence in all cell types and tissues before Cre-recombination and green fluorescence following Cre-recombination (Muzumdar et al., 2007). Col2CreER ${ }^{T 2}$ mice were bred with $\operatorname{Ros}^{m T / m G}$ mice to generate Col2CreER ${ }^{T 2}$; Rosa ${ }^{m T / m G}$ mice. Tamoxifen was administered into 2-week-old mice by i.p. injection ( $1 \mathrm{mg} / 10 \mathrm{~g}$ body weight for $5 \mathrm{~d}$ ). Skulls were dissected, fixed in $0.2 \%$ glutaraldehyde at $4{ }^{\circ} \mathrm{C}$ for $4 \mathrm{~d}$, followed by washing three times with phosphate buffered saline (PBS). Samples were decalcified in $14 \%$ EDTA at $4{ }^{\circ} \mathrm{C}$ for 3 weeks, cryo-protected in $30 \%$ sucrose at $4{ }^{\circ} \mathrm{C}$ for $3 \mathrm{~d}$, and then embedded and processed for frozen sections. $3 \mu \mathrm{m}$ thick sections were imaged with a fluorescence microscope.

\section{Immunohistochemistry}

$3 \mu \mathrm{m}$-thick paraffin sections were baked at $60^{\circ} \mathrm{C}$ overnight. Slides were then deparaffinised, and rehydrated. Antigen retrieval of collagen II and collagen $\mathrm{X}$ was performed using $0.2 \mathrm{~g}$ pepsin in $50 \mathrm{~mL}$ of $0.01 \mathrm{~N} \mathrm{HCl}$ at $37^{\circ} \mathrm{C}$ for $25 \mathrm{~min}$. Antigen retrieval of Runx 2 was performed using a $0.01 \mathrm{M}$ citrate buffer $\mathrm{pH} 6.0$ at $95{ }^{\circ} \mathrm{C}$ for $2 \mathrm{~h}$. Dako endogenous blocking reagent (S2003, Dako, Carpinteria, CA, USA) was then used to quench endogenous peroxidase for $10 \mathrm{~min}$. Non-specific binding sites were blocked with 1:20 normal horse/goat serum (S-2000, Vector Laboratories, Burlingame, CA, USA) for $20 \mathrm{~min}$ at room temperature. 1:80 dilution $(2.5 \mu \mathrm{g} / \mathrm{mL})$ of collagen II (MS-235-P, Thermo Scientific, Rockford, IL, USA), 1:50 dilution of collagen X (2031501005, Quartett, Berlin, Germanv), or 1:100 dilution $(10 \mu \mathrm{g} / \mathrm{mL})$ of Runx2 (D130-3, MBL International, Woburn, MA, USA) primary antibodies were added and the slides were incubated at $4{ }^{\circ} \mathrm{C}$ overnight. Secondary biotinylated horse anti-mouse antibody (BA2000, Vector Laboratories) or goat anti-mouse antibody (BA-9200, Vector Laboratories) at the dilution of 1:200 was added for $30 \mathrm{~min}$ on the second day, followed by incubation with 1:250 streptavidin (21130, Pierce, Rockford, IL, USA) for $30 \mathrm{~min}$. Positive staining was detected by Romulin AEC Chromagen (Biocare Medical RAEC810L, Concord, CA, USA).

\section{Cell proliferation and apoptosis assays}

We dissected TMJs from $\beta$-catenin (ex 3$)^{\text {Col2ER }}$ mice and Cre-negative control mice. Samples were fixed in $10 \%$ formalin, decalcified, and embedded in paraffin. The condyles were sectioned into serial sections at $3 \mu \mathrm{m}$ thick in an anterior-posterior direction. Cell proliferation was carried out using anti-PCNA antibody at the dilution of 1:200 (ab18197, ABCAM ${ }^{\circledR}$, Cambridge, UK). Apoptosis assay was carried out using a TUNEL assay kit according to the manufacturer's instructions (G3250, Promega, Madison, WI, USA).

\section{Real-time PCR analysis}

1 -month-old $\beta$-catenin(ex3) Col2ER mice and their Crenegative control mice were sacrificed. TMJ cartilage was collected from freshly sacrificed mice to obtain total RNA. After washing with sterile PBS 3 times, the TMJ cartilage tissue was digested in $1 \%$ pronase (Roche, Basel, Switzerland) and dissolved in 1x PBS for $30 \mathrm{~min}$ in a $37^{\circ} \mathrm{C}$ water bath with continuous shaking. This was followed by washing with serum-free Dulbecco's modified Eagle medium (DMEM) 3 times. The TMJ cartilage tissue was then digested in $1 \%$ Collagenase A (Roche) dissolved in serum-free DMEM for $3 \mathrm{~h}$ in a $37^{\circ} \mathrm{C}$ water bath with continuous shaking. DMEM with $10 \%$ foetal bovine serum (FBS) was then added to stop digestion and a $40 \mu \mathrm{m}$ cell strainer was used to filter the digestion solution. Cells were collected and RNA was extracted using Trizol reagent (Invitrogen, Carlsbad, CA, USA) according to the manufacturer's instructions. $1 \mu \mathrm{g}$ aliquots of RNA were

Table 4. Name and sequences of PCR primers.

\begin{tabular}{|l|l|}
\hline Primer Name & Sequence \\
\hline Runx2 (forward) & 5'-GAGGGCACAAGT TCTATCTGGA-3' \\
Runx2 (reverse) & 5'-GGTGGT CCGCGATGATCTC-3' \\
Col10a1 (forward) & 5'-ACCCCAAGGACCTAAAGGAA-3' \\
Col10a1 (reverse) & 5'-CCCCAGGATACCCTGTTTTT-3' \\
Mmp13 (forward) & 5'-TTTGAGAACACGGGGAAGA-3' \\
Mmp13 (reverse) & 5'-ACTTTGTTGCCAATTCCAGG-3' \\
Adamts4 (forward) & 5'-GGCAGATGACAAGATGGCAGCATT-3', \\
Adamts4 (reverse) & 5'-AGACGAGTCACCACCAAGTTGACA-3' \\
Adamts5 (forward) & 5'-CCAAATGCACTTCAGCCACGATCA-3', \\
Adamts5 (reverse) & 5'-AATGTCAAGTTGCACTGCTGGGTG-3' \\
\hline
\end{tabular}


reverse transcribed into cDNA using the iScript cDNA Synthesis Kit (Bio-Rad, Hercules, CA, USA). Real time PCR was performed using the Rotor Gene (RG 6000, Rotor Gene, Hilden, Germany) real time DNA amplification system (Corbett Research, Westborough, MA, USA) according to the manufacturer's instructions. Reactions were performed in a $20 \mu \mathrm{L}$ final volume containing cDNA samples, $50 \mu \mathrm{M}$ primers of interest, and SYBR green master mix (Applied Biosystems, Foster City, CA, USA) for PCR amplification. The name and sequence of PCR primers are listed in Table 4.

\section{Statistical analysis}

The values are presented as mean \pm standard error, and error bars represent standard error. For comparison of two groups of data, unpaired Student's $t$-test was performed. For comparison of multiple groups of data, one-way analysis of variance (ANOVA) was performed followed by Dunnett's test. * $p<0.05$ was considered as significant difference between groups.

\section{Results}

High Cre-recombination efficiency in TMJ cartilage To evaluate Col2-Cre expression and recombination efficiency in the TMJ cartilage, Col2 CreER ${ }^{T 2}$ mice were bred with $\operatorname{Rosa}^{m T / m G}$ reporter mice to generate Col2 $\mathrm{CreER}^{T 2} ; \mathrm{Rosa}^{m T / m G}$ mice. Tamoxifen was administered when the mice were 2-week-old and TMJ samples were harvested at 1-month-old. The red fluorescent image of TMJ cartilage in Cre-negative control mice revealed absence of Col2Cre-expressing cells (Fig. 1C, upper panel), and the green-labelled chondrocytes in Col2CreER ${ }^{T 2}$ mice showed Col2Cre-expressing cells (Fig. 1C, lower panel). IHC assay showed that $\beta$-catenin overexpression was detected at the edges of TMJ cartilage (Fig. 1D). These results demonstrate that TMJ chondrocytes were targeted by Col2CreER ${ }^{T 2}$ mice with high efficiency.

\section{Conditional activation of $\beta$-catenin induces TMJ cartilage defects}

$\beta$-catenin(ex3) Col2ER mice were generated by crossing Col2CreER $R^{T 2}$ mice with $\beta$-catenin (ex3) fox fflox mice (Table 1 ) and the role of $\beta$-catenin in TMJ tissue function was investigated. Tamoxifen was administered to 2 -week-old mice and TMJ samples were harvested from these mice at 1, 3 and 6 months of age. One-month-old control mice showed thick and intact TMJ cartilage, which stained positive with Alcian blue. Furthermore, the chondrocytes in the control mice were well-organised in the three layers: smaller and round cells in the top superficial layer; medium-sized cells sitting in the lacuna were present in large numbers in the middle layer; and fewer, bigger, hypertrophic, mature cells in the deep layer (Fig. 2A). In contrast, 1-month-old $\beta$-catenin(ex3) ${ }^{\text {Col2ER }}$ mice already presented early signs of TMJ OA: decreased chondrocyte numbers in the superficial layer accompanied with less Alcian blue staining in this area, cells in the middle and deep layers illustrated increased hypertrophy, and the cartilage was thinner. At 3 months of age, articular chondrocyte numbers in the superficial and middle layers of TMJ cartilage of $\beta$-catenin(ex3) Col2ER mice were drastically reduced; hypertrophic cells were still present in the deep layer. However, total TMJ cartilage exhibited visibly reduced Alcian blue staining, demonstrating a decrease in proteoglycan levels (Fig. 2A). At 6 months of age, increased severity of defects in TMJ tissue was observed in $\beta$-catenin(ex3) Col2ER mice. In addition to decreased cellularity of the middle and deep layers of cartilage, decreased cartilage area and subchondral bone sclerosis were also observed (Fig. 2A). Compared to middle and deep layers, the superficial area of TMJ cartilage is relatively normal. This is probably because the superficial layer of TMJ cartilage was not targeted by Col2-directed $\beta$-catenin expression. These results were further confirmed by $\mu C T$. Significant reduction in TMJ joint space was observed in 3- and 6-month-old $\beta$-catenin (ex3) Col2ER $^{\text {- }}$ mice (Fig. 2B). Histomorphometric analysis revealed that the total cartilage area and total cartilage thickness were significantly decreased in $\beta$-catenin $(\text { ex } 3)^{\text {Col2ER }}$ mice compared to age-matched Cre-negative control mice. The total cartilage area decreased $22 \%$ in $\beta$-catenin $(\text { ex } 3)^{\text {Col2ER }}$ mice compared to their Cre-negative littermate controls at 1 month of age, and decreased $41 \%$ and $48 \%$ in 3 - and

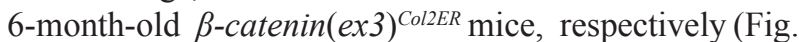
$2 \mathrm{C})$. These results were consistent with the quantification of total cartilage thickness. Cartilage thickness decreased $21 \%, 39 \%$ and $40 \%$ in $\beta$-catenin (ex 3$)^{\text {Col } 2 E R}$ mice at 1,3 and 6 months of age, respectively, compared to Cre-negative controls (Fig. 2D).

\section{Histology and IHC analyses of $\beta$-catenin(ex3) Col2ER mice}

To further investigate OA related pathological alterations in $\beta$-catenin (ex3) Col2ER mice, Safranin O/Fast green ( $\mathrm{SO} /$ $\mathrm{FG}$ ) staining was performed to assess changes in aggrecan levels in 3-month-old mice. Although the integrity of the TMJ articular surface was maintained, aggrecan expression as indicated by red staining was reduced in $\beta$-catenin(ex3)

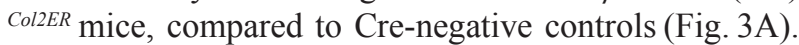
Immunohistochemistry (IHC) revealed decreased Col2 expression in the $\beta$-catenin $(\text { ex } 3)^{\text {Col2ER }}$ mice. In addition, IHC results also showed significantly increased Runx 2 and Col10 expression in $\beta$-catenin(ex3) Col2ER mice compared to controls, indicating the chondrocytes underwent hypertrophy at this stage (Fig. 3A). The result of PCNA staining showed that there were no significant changes in PCNA staining in TMJ tissues of $\beta$-catenin (ex3) Col2ER mice, suggesting that overexpression of $\beta$-catenin in TMJ tissue did not affect TMJ cell proliferation (Fig. 3B). Data of TUNEL staining demonstrated an increase in numbers of apoptotic cells compared to that in control mice, but did not reach statistical significance between $\beta$-catenin(ex3) Col2ER and control mice (Fig. 3C). Taken in concert, these results indicate that conditional activation of $\beta$-catenin in the TMJ induces degenerative defects that may not be due to changes in cell proliferation and apoptosis.

Gene expression analysis of $\beta$-catenin (ex3) Col2ER mice To determine changes in gene expression in the TMJ cartilage, cells were isolated from TMJ cartilage of 

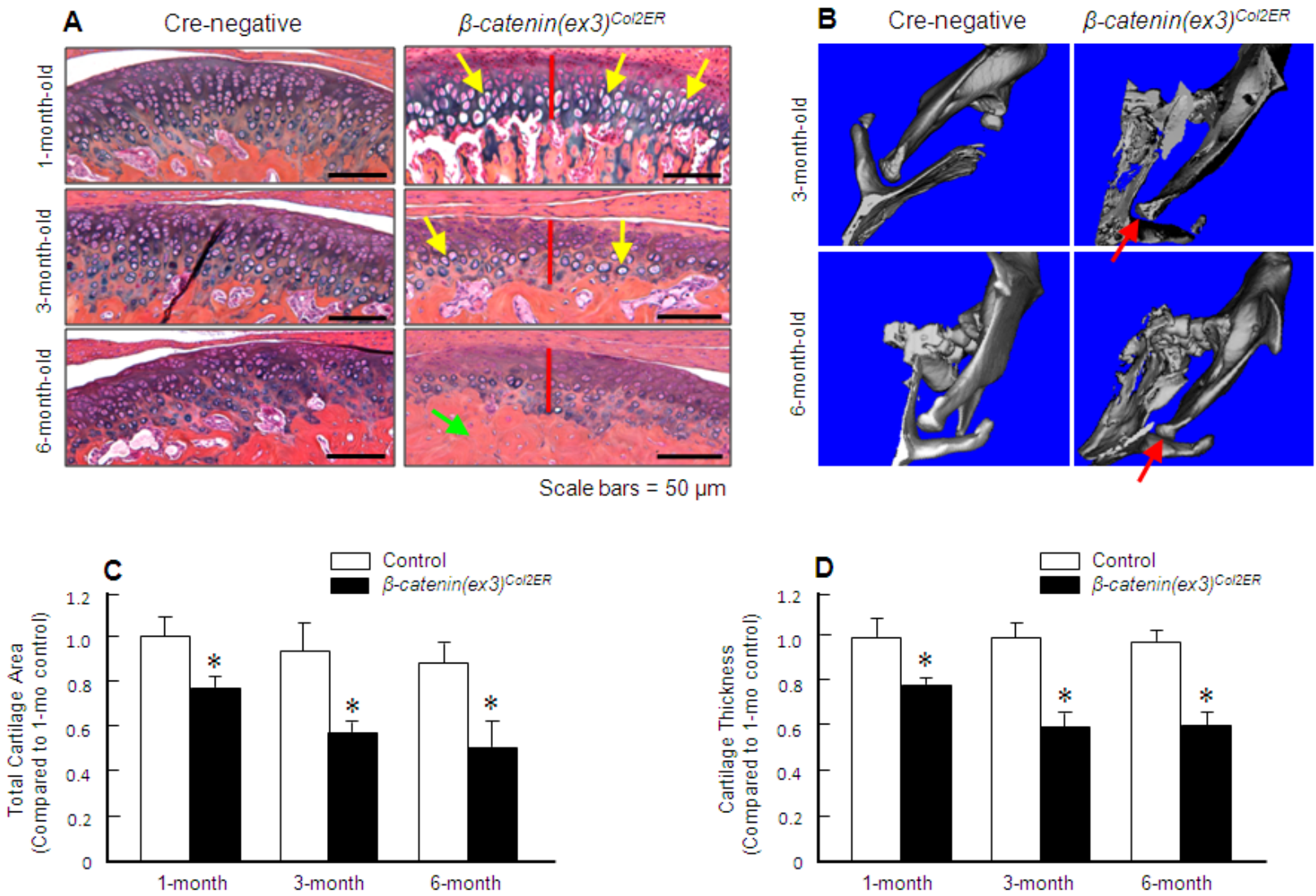

Fig. 2. Activation of $\beta$-catenin induces a TMJ OA-like phenotype. (A) Tamoxifen was administered into 2-weekold $\beta$-catenin (ex3) ${ }^{\text {Col2ER }}$ mice and Cre-negative control littermates $(1 \mathrm{mg} / 10 \mathrm{~g}$ body weight, i.p., daily for $5 \mathrm{~d}$ ). TMJ samples were harvested when the mice were 1-, 3- or 6-month-old and Alcian blue/H\&E staining was performed. Histology results showed increased cartilage degradation in 1-, 3- and 6-month-old $\beta$-catenin (ex3) ${ }^{\operatorname{Col} 2 E R}$ mice compared to Cre-negative control mice. Large numbers of hypertrophic chondrocytes were identified in 1- and 3-month-old $\beta$-catenin(ex3) Col2ER mice (yellow arrows). Severe subchondral sclerosis was found in 6-month-old $\beta$-catenin (ex3) ${ }^{\text {Col2ER }}$ mice (green arrow). Reduction in cartilage thickness in 1-, 3- and 6-month-old $\beta$-catenin(ex3) Col2ER mice is indicated by red bars. (B) $\mu \mathrm{CT}$ images of 3 - and 6-month-old $\beta$-catenin (ex3) $)^{\text {Col2ER }}$ mice showed decreased disc space in $\beta$-catenin (ex3) Col2ER mice (red arrows) compared to control mice. (C) Total TMJ cartilage area was quantified by tracing the Alcian blue-positive area. Cartilage area decreased $22 \%, 41 \%$ and $48 \%$ in 1-, 3- and 6- month-old $\beta$-catenin (ex3) ${ }^{\text {Col2ER }}$ mice compared to the same aged control mice $(* p<0.05$, unpaired Student $t$-test, $n=5$ ). (D) Total cartilage thickness was quantified by tracing the Alcian blue-positive thickness in the centre of the TMJ cartilage. Total cartilage thickness decreased $21 \%, 39 \%$ and $40 \%$ in 1-, 3- and 6-month-old $\beta$-catenin $(\text { ex } 3)^{\text {Col2ER }}$ mice compared to the same aged control mice $\left({ }^{*} p<0.05\right.$, unpaired Student $t$-test, $\left.n=5\right)$.

1-month-old mice. RT-PCR results were consistent with IHC findings. Runx2 (Fig. 4A) and Col10 (Fig. 4B) expression were increased 2.8 and 4.1 fold, respectively, in $\beta$-catenin (ex3) ${ }^{\text {Col2ER }}$ mice compared to control mice.

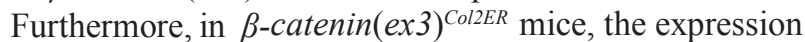
of genes encoding cartilage degrading enzymes, such as Mmp13 (Fig. 4C), Adamts4 (Fig. 4D), and Adamts5 (Fig. $4 \mathrm{E}$ ) was increased 4.5, 2.7 and 4.0 fold, respectively. These results suggest that the activation of $\beta$-catenin signalling could lead to chondrocyte hypertrophy and degenerative defects.

\section{Ameliorated TMJ defects by deletion of the Mmp13 or Adamts5 gene}

To assess the roles of MMP13 and Adamts 5 in the development of TMJ defects, $(\beta$ - catenin(ex3)/Mmp13)
Col2ER and $\beta$-catenin (ex3) Col2ER/Adamts $5^{-/}$double mutant mice were generated (Tables 2 and 3). Tamoxifen was administered when the mice were 2 -week-old and histology analysis was performed. In 3-month-old mice, TMJ defect progression was markedly decelerated in both $(\beta \text {-catenin(ex3)/Mmp13) })^{\text {Col2ER }}$ and $\beta$-catenin(ex3) Col2ER $/$ Adamts $5^{-/}$double mutant mice (Figs. 5A and B) compared to $\beta$-catenin (ex3) Col2ER mice (Fig. 2A). Histology results showed a greater amount of intact cartilage and more pronounced Alcian blue and SO/FG staining in the double mutant mice, indicating higher collagen and aggrecan content in the cartilage. Results of histomorphometry also showed that TMJ defects were decelerated after deletion of either the Mmpl3 or Adamts 5 gene in $\beta$-catenin(ex3) Col2ER mice (Figs. $5 \mathrm{C}$ and D). Compared to the 3 -month-old $\beta$-catenin $(\operatorname{ex} 3)^{\text {Col2ER }}$ 

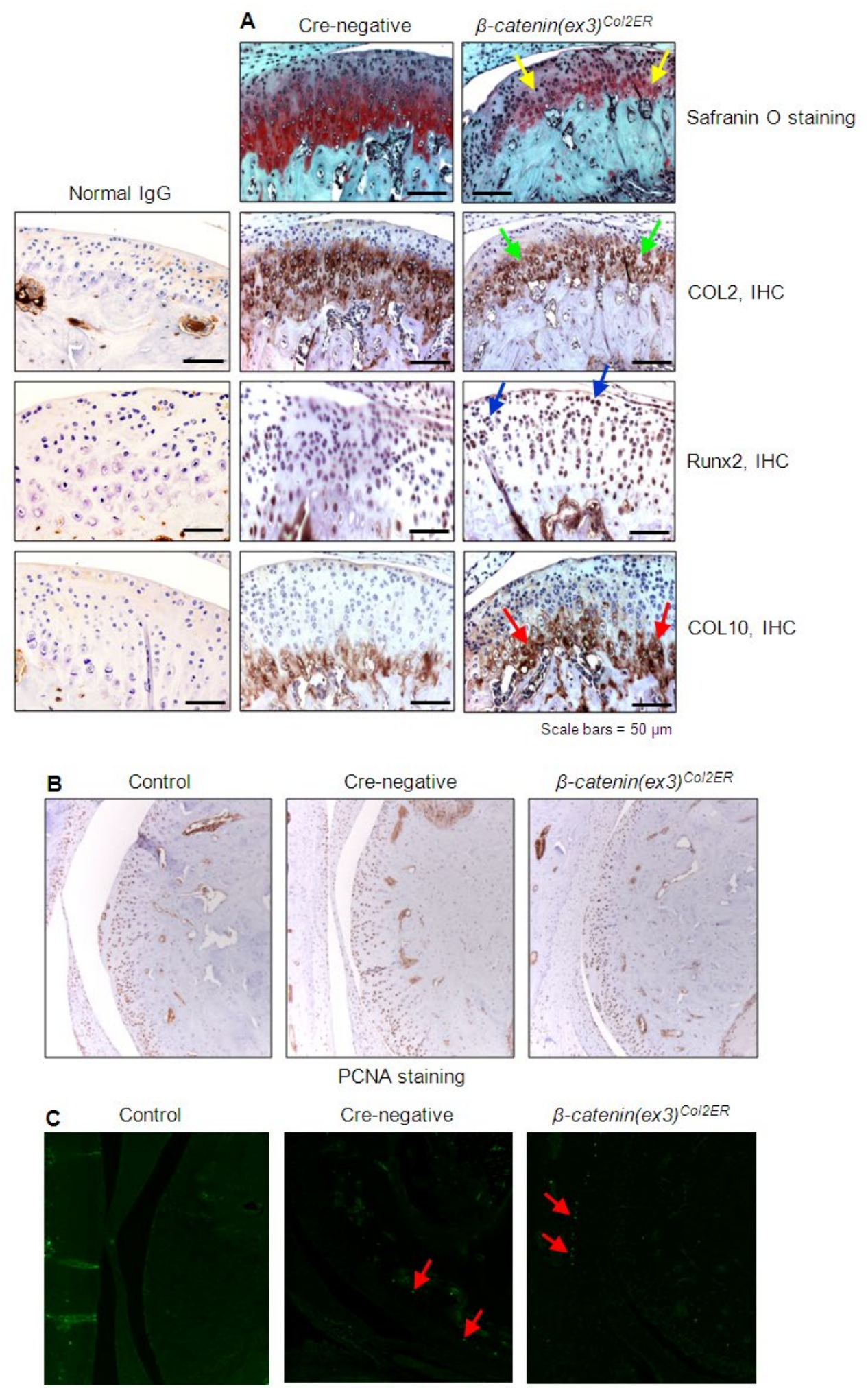

$\beta$-catenin $(e \times 3)^{\text {Col2ER }}$

TUNNEL staining

Fig. 3. Alterations in matrix protein expression, cell proliferation and apoptosis in $\beta$-catenin $(\text { ex } 3)^{\text {Col2ER }}$ mice. Tamoxifen was administered when $\beta$-catenin (ex3) ColzR and Cre-negative control mice were 2 -week-old $(1 \mathrm{mg} / 10 \mathrm{~g}$ body weight, i.p., daily for 5 d). TMJ cartilage samples were harvested at 3-month-old. (A) Safranin O/fast green staining was performed to evaluate aggrecan levels. Results showed that aggrecan levels were significantly reduced in $\beta$-catenin(ex3) ${ }^{\text {Col2ER }}$ mice (yellow arrows). IHC was performed to detect changes in COL2, Runx2 and COL10 protein expression in $\beta$-catenin (ex3) ${ }^{\text {Col2ER }}$ mice. IHC results showed that COL2 expression was significantly decreased (green arrows), and expression of Runx2 (blue arrows) and COL10 (red arrows) was significantly increased in $\beta$-catenin (ex3) Col2ER mice. PCNA (B) and TUNNEL (C) staining was performed in TMJ tissues derived from Cre-negative control and $\beta$-catenin $(\text { ex3 })^{\text {Col2ER }}$ mice. Results showed that there were no significant changes in cell proliferation (PCNA staining) and apoptosis (TUNNEL staining) in $\beta$-catenin(ex3) CllERR $^{\text {mice. }}$ 

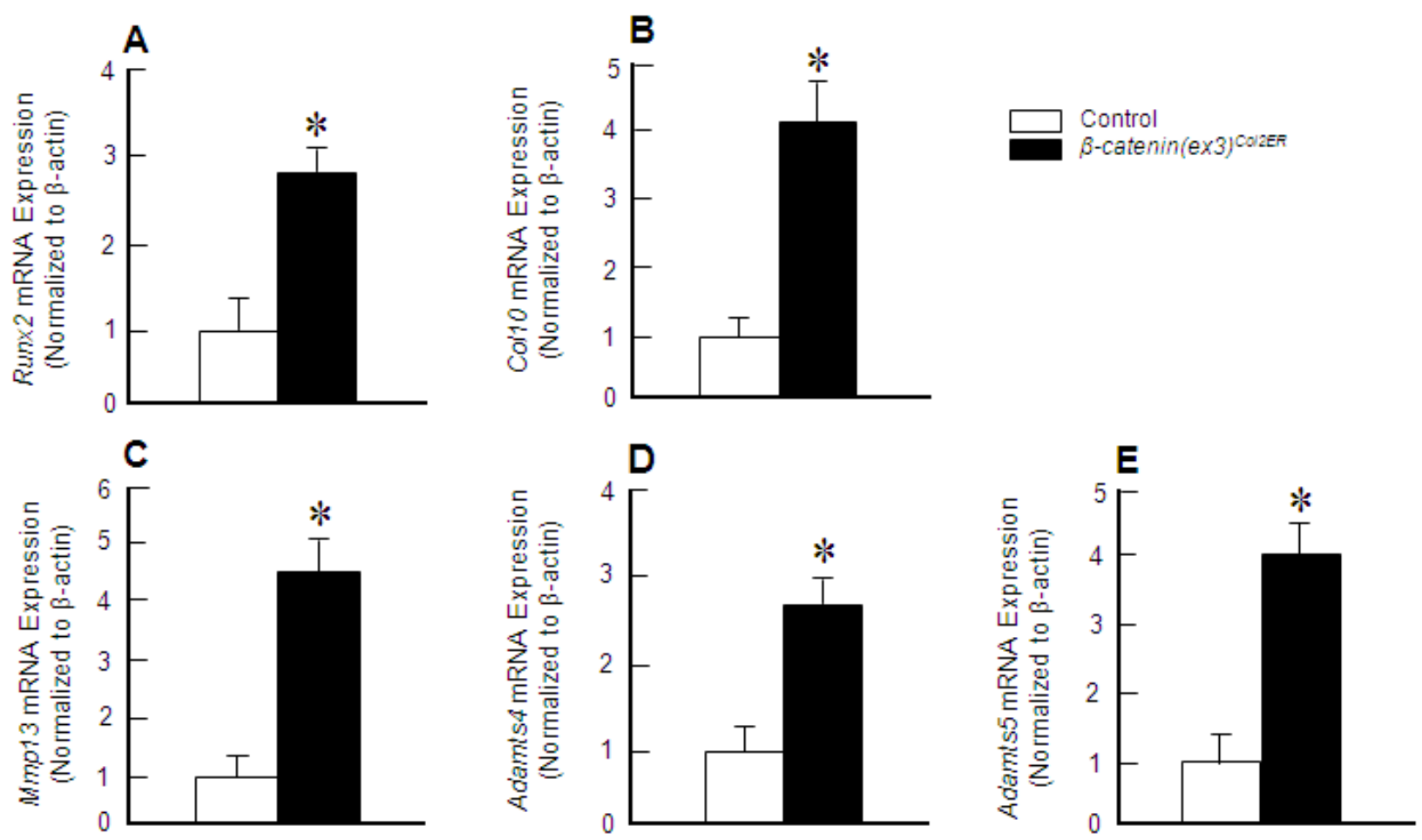

Fig. 4. Alterations in gene expression in $\beta$-catenin (ex3) Col2ER mice. Total RNA was extracted from TMJ tissues from

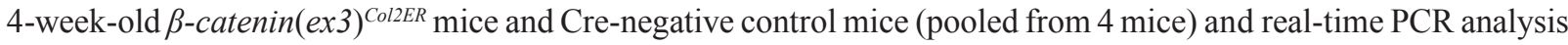
was performed. The results showed that expression of Runx2 (A), Col10 (B), Mmp13 (C), Adamts4 (D), and Adamts5 (E) was significantly increased 2.8, 4.1, 4.5, 2.7 and 4.0 fold, respectively, in TMJ tissues derived from $\beta$-catenin(ex3) Col2ER mice $\left({ }^{*} p<0.05\right.$, unpaired Student $t$-test, $\left.n=3\right)$.

Table 5. Deletion of the Mmp13 or Adamts 5 gene reverses the TMJ OA phenotype observed in 3- and 6-monthold $\beta$-catenin (ex3) Col2ER mice.

\begin{tabular}{|c|c|c|c|c|}
\hline Mouse group & Cartilage area* & $\%$ Area recovery ${ }^{\pi}$ & Cartilage thickness* & $\%$ Thickness recovery \\
\hline $\begin{array}{l}\beta \text {-catenin }(\operatorname{ex3})^{\text {ColleR }} \\
(3 \text {-month-old) }\end{array}$ & $59 \%$ & & $61 \%$ & \\
\hline $\begin{array}{l}{\left[\beta \text {-catenin }(\text { ex3)/Mmp13] }]^{\text {Col2ER }}\right.} \\
\text { (3-month-old) }\end{array}$ & $92 \%$ & $33 \%$ & $94 \%$ & $33 \%$ \\
\hline $\begin{array}{l}\beta \text {-catenin }(\text { ex3 })^{\text {Col2ER }} / \text { Adamts 5- } \\
(3 \text {-month-old) }\end{array}$ & $87 \%$ & $28 \%$ & $75 \%$ & $14 \%$ \\
\hline $\begin{array}{l}\beta \text {-catenin }\left(\text { ex3) }{ }^{\text {Col2ER }}\right. \\
(6 \text {-month-old) }\end{array}$ & $52 \%$ & & $60 \%$ & \\
\hline $\begin{array}{l}{\left[\beta \text {-catenin }(\text { ex3)/Mmp13] }]^{\text {Col2ER }}\right.} \\
\text { (6-month-old) }\end{array}$ & $78 \%$ & $26 \%$ & $70 \%$ & $10 \%$ \\
\hline $\begin{array}{l}\beta \text {-catenin }(\text { ex3 })^{\text {Col2ER }} / \text { Adamts }^{-/-} \\
\text {(6-month-old) }\end{array}$ & $73 \%$ & $21 \%$ & $66 \%$ & $6 \%$ \\
\hline
\end{tabular}

* Compared to the Cre-negative littermate controls.

^ Compared to $\beta$-catenin(ex3) ${ }^{\text {Col2ER }}$ mice.

mice, the loss of cartilage area was reversed 33 and $28 \%$ in $(\beta \text {-catenin (ex3)/Mmp13) })^{\text {Col2ER }}$ and $\beta$-catenin $(\text { ex3 })^{\text {Col2ER } /}$ Adamts $5^{-/}$double mutant mice. Compared to the 6-monthold $\beta$-catenin (ex3) ${ }^{\text {Col2ER }}$ mice, the loss of cartilage area was reversed 26 and $21 \%$ in these double mutant mice (Table $5)$. Detailed quantitative analyses revealed that there was a $41 \%$ cartilage loss in 3 -month-old $\beta$-catenin $(\text { ex } 3)^{\text {Col2ER }}$ mice. However, only a 8 and $13 \%$ cartilage area decrease was observed in 3-month-old ( $\beta$-catenin(ex3)/Mmp13)

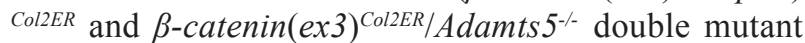
mice compared to Cre-negative controls (Fig. 5C and Table 5). In 6-month-old mice, there was a $48 \%$ cartilage

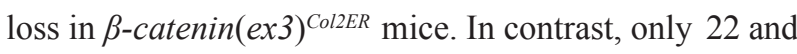
$27 \%$ of the cartilage area decreased in $(\beta$-catenin $($ ex 3$) /$ Mmp 13) $)^{\text {Col2ER }}$ and $\beta$-catenin(ex3) Col2ER/Adamts $5^{-/}$double mutant mice compared to Cre-negative controls (Fig. 5C and Table 5). These results demonstrated that the deletion of either Mmp13 or Adamts 5 gene can significantly reverse $\beta$-catenin activation-induced TMJ cartilage loss. Quantification of cartilage thickness showed similar results (Fig. 5D). There was a $39 \%$ decrease in cartilage thickness in $\beta$-catenin (ex3) ${ }^{\text {Col2ER }}$ mice. However, only a 6 and $25 \%$ decrease in cartilage thickness was observed in 3-monthold double mutant mice. In 6-month-old mice, there was 


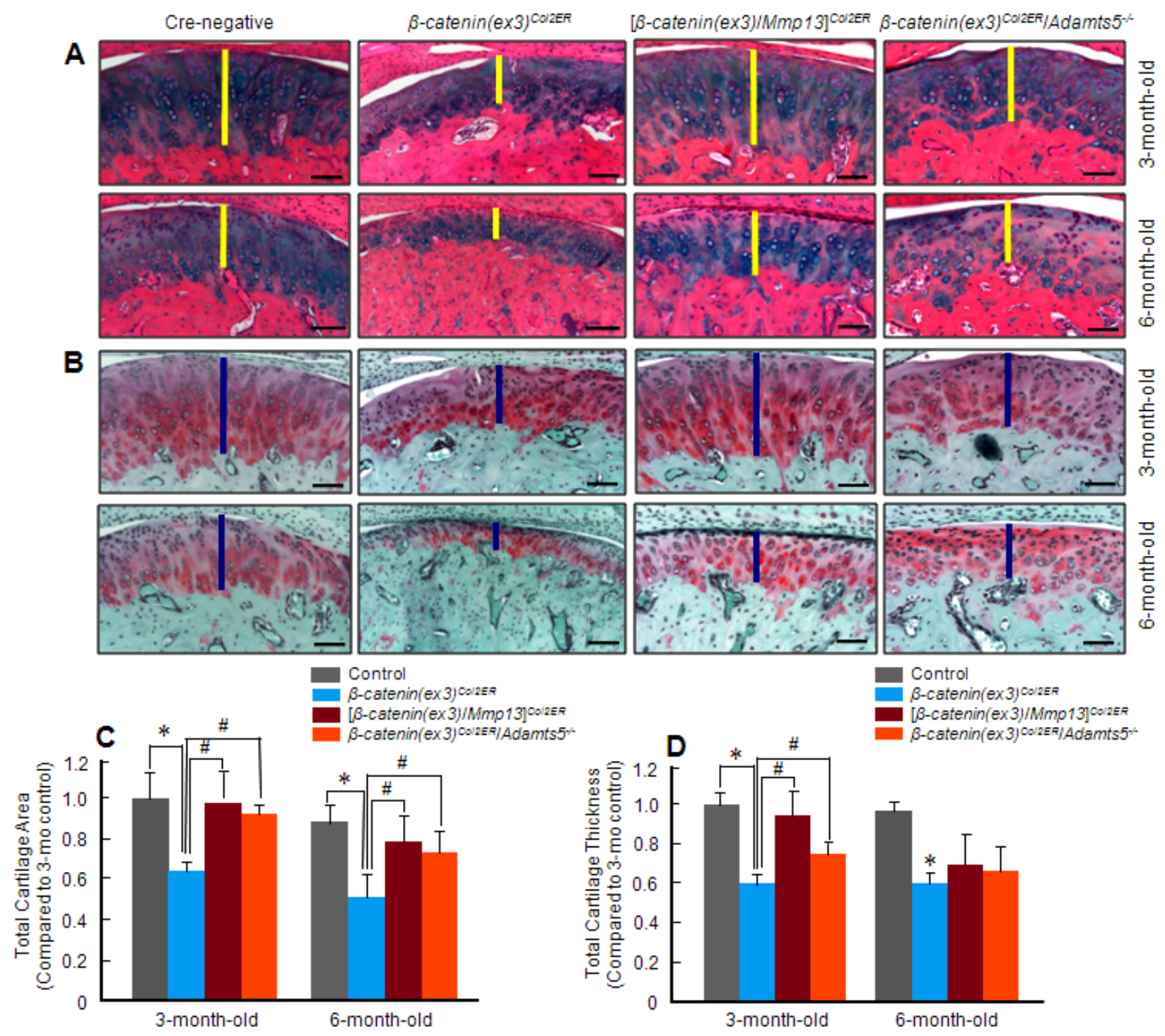

Fig. 5. OA-like phenotype was decelerated when either the Mmp13 or the Adamts5 gene was deleted in $\beta$-catenin (ex3) ${ }^{\text {COILR }}$ mice. Tamoxifen was administered into 2 -week-old mice $(0.1 \mathrm{mg} / \mathrm{g}$ body weight, i.p., daily for $5 \mathrm{~d}$ ). TMJ samples were harvested from 3- or 6-month-old mice and Alcian blue/H\&E and SO/FG staining were performed. Alcian blue/H\&E staining (A) and SO/FG staining (B) showed decelerated TMJ defect progression and more aggrecan contents in double mutant mice compared to those in $\beta$-catenin (ex3) ${ }^{\text {ColzER }}$ mice. (C) Total TMJ cartilage area was quantified by tracing the Alcian blue-positive area. Cartilage areas were 8 and $13 \%$ decreased

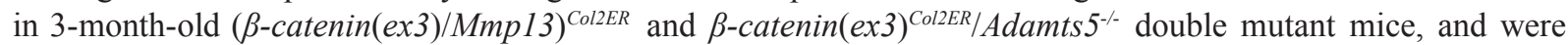
22 and $27 \%$ decreased in 6-month-old $\left(\beta\right.$-catenin $(\text { ex 3)/Mmp13) })^{\text {Col2ER }}$ mice and $\beta$-catenin $(\text { ex } 3)^{\text {Col2ER } / \text { Adamts } 5^{-/ /} \text {mice }}$ compared to the same age control mice $(* p<0.05$, compared to Cre-negative control group; $* * p<0.05$, compared to $\beta$-catenin(ex3) ${ }^{\text {Col2ER }}$ group; one-way ANOVA followed by Dunnett's test, $n=5$ ). (D) Total cartilage thickness was quantified by tracing the Alcian blue-positive thickness in the centre of the TMJ cartilage. Total cartilage thickness was decreased 6 and $25 \%$ in 3-month-old double mutant mice and 30 and $34 \%$ decreased in 6-monthold double mutant mice compared to the same age control mice $(* p<0.05$, compared to Cre-negative control group; $* * p<0.05$, compared to $\beta$-catenin(ex3) Col2ER group; one-way ANOVA followed by Dunnett's test, $n=5$ ).

a $40 \%$ decrease in cartilage thickness in $\beta$-catenin(ex3) COLER mice. In contrast, only a 30 and $34 \%$ decrease in cartilage thickness was observed in 6-month-old double mutant mice (Fig. 5D and Table 5). Statistical analysis results demonstrated a significant decrease in cartilage thickness in 3-month-old $\beta$-catenin(ex3) Col2ER mice. Compared to $\beta$-catenin (ex3) Col2ER mice, the reduction of cartilage thickness was significantly reversed in 3-monthold double mutant mice (Fig. 5D).

\section{Discussion}

Although TMJ OA is a common degenerative joint disease, the pathological mechanisms of this disease remain largely unknown. In this study, we generated a genetic mouse model and demonstrated that overexpression of $\beta$-catenin in TMJ chondrocytes leads to degenerative defects resembling an OA-like phenotype in the TMJ cartilage. Furthermore, deletion of the Mmp13 or Adamts 5 gene 
in $\beta$-catenin(ex3) $)^{\text {Col2ER }}$ mice significantly and partially rescued TMJ defects observed in $\beta$-catenin (ex3) Col2ER mice.

It has been shown that $\beta$-catenin protein expression was highly-upregulated in articular cartilage tissues from patients with knee OA (Zhu et al., 2009) and in intervertebral disc tissues from patients with degenerative disc disease (Wang et al., 2012). Col2-driven cartilagespecific activation of $\beta$-catenin in mice leads to a knee joint OA-like phenotype and defects in intervertebral disc tissues (Zhu et al., 2009; Wang et al., 2012). Here, we further demonstrated that Col2-driven $\beta$-catenin (ex3) Col2ER mice also showed TMJ degenerative defects. Even though articular cartilage in the knee joint is hyaline cartilage, and IVD tissue and TMJ cartilage are composed of both hyaline cartilage and fibrocartilage, the mechanisms of degeneration in these tissues are very similar. Moreover, in our study we specifically determine the role of $\beta$-catenin signalling in Col2-Cre targeting cells. Among articular cartilage, TMJ cartilage and disc tissues, it seems that knee joint articular cartilage was most efficiently targeted by Col2-Cre due to high Col2 expression in this tissue compared to IVD tissue and TMJ cartilage (Chen et al., 2007; Zhu et al., 2008; Jin et al., 2011; Fig. 1).

To determine changes in gene expression in TMJ tissues with degenerative defects in $\beta$-catenin(ex3) Col2ER mice, we isolated TMJ cartilage tissues. We found that RT-PCR results are consistent with the SO/FG and IHC results. Runx2 and Collo are two hypertrophic markers in cartilage during OA development, and their expression levels were increased in $\beta$-catenin $(\text { ex } 3)^{\text {Col2ER }}$ mice. The RT-PCR results also revealed increases in the expression of genes encoding collagenase (MMP13) and aggrecanases (Adamts4 and Adamts5) in $\beta$-catenin(ex3) Col2ER mice. It has been shown that MMP13 and Adamts5 are the primary enzymes leading to cartilage degeneration (Neuhold et al., 2001; Glasson et al., 2005; Wang et al., 2013), and Adamts5 may play a more crucial role in cartilage degradation compared to Adamts4 (Glasson et al., 2004). We thus generated ( $\beta$-catenin(ex3)/Mmp13) ${ }^{\text {Col2ER }}$ and $\beta$-catenin $(\text { ex } 3)^{\text {Col2ER }} /$ Adamts $5^{-/}$double mutant mice to determine roles of Mmp13 and Adamts 5 in $\beta$-catenin signalling during TMJ tissue degeneration. Our results showed decelerated TMJ defects in both of these double mutant mice. Although deletion of the Mmp 13 or Adamts 5 gene significantly decreased TMJ defects observed in $\beta$-catenin (ex3) Col2ER mice, normal cartilage phenotype was not completely restored by deletion of either Mmp13 or Adamts5. There was still a significant loss of proteoglycans in these double mutant mice compared to Cre-negative controls. The possible reason to account for this could be that Mmp13,Adamts 4 and Adamts5, as well as other catabolic factors, contribute to OA development (Stanton et al., 2005; Glasson et al., 2005; Majumdar et al., 2007), and deletion of only one of them may not be able to completely inhibit cartilage degeneration.

Moreover, our results indicate that the deletion of the Mmp13 gene in the $\beta$-catenin(ex3) ${ }^{\text {Col2ER }}$ background seems more effective in preventing OA progression than deletion of the Adamts 5 gene. This is probably because MMP13 preferentially cleaves the proteolysis of $\mathrm{Col} 2$, which is the most abundant matrix protein in the TMJ cartilage. MMP13 also targets aggrecan, types IV and IX collagens, gelatin, osteonectin and perlecan in cartilage for degeneration (Shiomi et al., 2010). In contrast, Adamts5 is an aggrecanase that is mainly responsible for aggrecan degradation. Therefore, deletion of the Mmp13 gene is likely to prevent the degradation of more substrates responsible for cartilage degeneration compared to deletion of Adamts5.

Recent reports demonstrated that $\beta$-catenin signalling is responsive to mechanical loading (Lin et al., 2009; Premaraj et al., 2013; Javaheri et al., 2014). Abnormal occlusion could lead to OA development in TMJ tissue (Zhang et al., 2013; Liu et al., 2014). We hypothesise that one of the major upstream regulatory factors for $\beta$-catenin signalling in TMJ tissue is mechanical loading. In the future, we will examine if abnormal occlusion (causing mechanical changes in TMJ tissue) will induce $\beta$-catenin signalling activation in TMJ tissue. In addition to mechanical loading, growth factors involved in inflammation, such as tumour necrosis factor- $\alpha$ (TNF- $\alpha)$ and interleukin $1 \beta$ (IL-1 $\beta$ ) could be potentially important upstream regulators for $\beta$-catenin signalling in TMJ tissues. It has been reported that TNF- $\alpha$ and IL- $1 \beta$ regulate $\beta$-catenin signalling in other tissues (Kitazawa et al., 2011; Raymond et al., 2012; Gong et al., 2014). Regarding the mechanism of $\beta$-catenin overexpression-induced defects in TMJ tissue, we propose that one of the major downstream mediators for $\beta$-catenin signalling in the TMJ tissue is Runx2. Activation of $\beta$-catenin causes up-regulation of Runx2, which subsequently promotes Mmp13 and Adamts 5 expression in TMJ tissues (Figs. 3 and 4; Wang et al., 2012).

It has been shown that conditional activation of $\beta$-catenin in knee cartilage and intervertebral disc cartilage induce knee $\mathrm{OA}$ and disc tissue degeneration. $\beta$-catenin plays a key role in the activation of downstream target genes, such as Mmp13, Adamts4 and Adamts5 in cartilage, leading to the development of knee OA and disc degeneration (Wang et al., 2012). The current study is the first to demonstrate that the same signalling mechanism can also induce TMJ cartilage degradation. The potential mechanisms for $\beta$-catenin activation in patients with TMJ OA may include activating mutations of the $\beta$-catenin gene (Morin et al., 1997; Simon et al., 2005; Jamieson et al., 2004; Derksen et al., 2004), mechanical loading (Hens et al., 2005; Robinson et al., 2006; Sen et al., 2009) and inflammation (Johnson, 2009; Kaler et al., 2009). In summary, our studies suggest that $\beta$-catenin may play a role in TMJ cartilage function and may be a mediator in TMJ OA development. Mmp13 and Adamts 5 are important downstream targets of $\beta$-catenin signalling in TMJ chondrocytes during OA development.

\section{Acknowledgments}

This work was supported by Grants R01 AR055915 and R01 AR054465 to D.C. from the National Institutes of Health. The authors thank Verhonda Hearon-Eggleston for assistance in preparing the manuscript. The authors declare that no competing interests exist, and that the funders 
had no role in study design, data collection and analysis, decision to publish, or preparation of the manuscript.

\section{References}

Chen M, Lichtler AC, Sheu TJ, Xie C, Zhang X, O'Keefe RJ, Chen D (2007) Generation of a transgenic mouse mode with chondrocyte-specific and tamoxifeninducible expression of Cre recombinase. Genesis 45: 44-50.

de Bont LG, van der Kuijl B, Stegenga B, Vencken LM, Boering G (1993) Computed tomography in differential diagnosis of temporomandibular joint disorders. Int J Oral Maxillofac Surg 22: 200-209.

de Leeuw R (2008) Orofacial Pain: Guidelines for Assessment, Diagnosis and Management. 4th ed. Quintessence Publishing, Chicago.

Derksen PW, Tjin E, Meijer HP, Klok MD, MacGillavry HD, van Oers MH, Lokhorst HM, Bloem AC, Clevers H, Nusse R, van der Neut R, Spaargaren M, Pals ST (2004) Illegitimate WNT signaling promotes proliferation of multiple myeloma cells. Proc Natl Acad Sci USA 101: 6122-6127.

Glasson SS, Askew R, Sheppard B, Carito BA, Blanchet T, Ma HL, Flannery CR, Kanki K, Wang E, Peluso D, Yang Z, Majumdar MK, Morris EA (2004) Characterization of and osteoarthritis susceptibility in ADAMTS-4-knockout mice. Arthritis Rheum 50: 2547 2558.

Glasson SS, Askew R, Sheppard B, Carito B, Blanchet T, Ma HL, Flannery CR, Peluso D, Kanki K, Yang Z, Majumdar MK, Morris EA (2005) Deletion of active ADAMTS5 prevents cartilage degradation in a murine model of osteoarthritis. Nature 434: 644-648.

Gong M, Liu C, Zhang L, Zhang H, Pan J (2014) Loss of the TNF $\alpha$ function inhibits Wnt/ $\beta$-catenin signaling, exacerbates obesity development in adolescent spontaneous obese mice. Mol Cell Biochem 391:59-66.

Harada N, Tamai Y, Ishikawa T, Sauer B, Takaku K, Oshima M, Taketo MM (1999) Intestinal polyposis in mice with a dominant stable mutation of the beta-catenin gene. EMBO J 18: 5931-5942.

Hens JR, Wilson KM, Dann P, Chen X, Horowitz MC, Wysolmerski JJ (2005) TOPGAL mice show that the canonical Wnt signaling pathway is active during bone development and growth and is activated by mechanical loading in vitro. J Bone Miner Res 20: 1103-1113.

Hirschmann PN, Shuttleworth CA (1976) The collagen composition of the mandibular joint of the foetal calf. Arch Oral Biol 21: 771-773.

Iwasaki LR, Crosby MJ, Marx DB, Gonzalez Y, McCall WD Jr, Ohrbach R, Nickel JC (2010) Human temporomandibular joint eminence shape and load minimization. J Dent Res 89: 722-727.

Jamieson CH, Ailles LE, Dylla SJ, Muijtjens M, Jones C, Zehnder JL, Gotlib J, Li K, Manz MG, Keating A, Sawyers CL, Weissman IL (2004) Granulocytemacrophage progenitors as candidate leukemic stem cells in blast-crisis CML. N Engl J Med 351: 657-667.
Javaheri B, Stern AR, Lara N, Dallas M, Zhao H, Liu Y, Bonewald LF, Johnson ML (2014) Deletion of a single $\beta$-catenin allele in osteocytes abolishes the bone anabolic response to loading. J Bone Miner Res 29: 705-715.

Jin H, Shen J, Wang B, Wang M, Shu B, Chen D (2011) TGF- $\beta$ signaling plays an essential role in the growth and maintenance of intervertebral disc tissue. FEBS Lett 585: 1209-1215.

Johnson A (2009) TNF-induced activation of pulmonary microvessel endothelial cells: a role for GSK3beta. Am J Physiol Lung Cell Mol Physiol 296: L700-709.

Kaler P, Augenlicht L, Klampfer L(2009) Macrophagederived IL-1beta stimulates Wnt signaling and growth of colon cancer cells: a crosstalk interrupted by vitamin D3. Oncogene 28: 3892-3902.

Kitazawa M, Cheng D, Tsukamoto MR, Koike MA, Wes PD, Vasilevko V, Cribbs DH, LaFerla FM (2011) Blocking IL-1 signaling rescues cognition, attenuates tau pathology, and restores neuronal $\beta$-catenin pathway function in an Alzheimer's disease model. J Immunol 187: 6539-6549.

Knäuper V, Lopez-Otin C, Smith B, Knight G, Murphy G (1996) Biochemical characterization of human collagenase-3. J Biol Chem 271: 1544-1550.

Kuroda S, Tanimoto K, Izawa T, Fujihara S, Koolstra JH, Tanaka E (2009) Biomechanical and biochemical characteristics of the mandibular condylar cartilage. Osteoarthritis Cartilage 17: 1408-1415.

Lin C, Jiang X, Dai Z, Guo X, Weng T, Wang J, Li Y, Feng G, Gao X, He L (2009) Sclerostin mediates bone response to mechanical unloading through antagonizing Wnt/beta-catenin signaling. J Bone Miner Res. 24:16511661.

Liu YD, Liao LF, Zhang HY, Lu L, Jiao K, Zhang M, Zhang J, He JJ, Wu YP, Chen D, Wang MQ (2014) Reducing dietary loading decreases mouse temporomandibular joint degradation induced by anterior crossbite prosthesis. Osteoarthritis Cartilage 22: 302-312.

Luder HU, Leblond CP, von der Mark K (1988) Cellular stages in cartilage formation as revealed by morphometry, radioautography and type II collagen immunostaining of the mandibular condyle from weanling rats. Am J Anat 182: 197-214.

Majumdar MK, Askew R, Schelling S, Stedman N, Blanchet T, Hopkins B, Morris EA, Glasson SS (2007) Double- knockout of ADAMTS-4 and ADAMTS-5 in mice results in physiologically normal animals and prevents the progression of osteoarthritis. Arthritis Rheum 56: 3670-3674.

McCulloch DR, Goff CL, Bhatt S, Dixon LJ, Sandy JD, Apte SS (2009a) Adamts5, the gene encoding a proteoglycan-degrading metalloprotease, is expressed by specific cell lineages during mouse embryonic development and in adult tissues. Gene Expr Patterns 9: 314-323.

McCulloch DR, Nelson CM, Dixon LJ, Silver DL, Wylie JD, Lindner V, Sasaki T, Cooley MA, Argraves WS, Apte SS (2009b) ADAMTS metalloproteases generate active versican fragments that regulate interdigital web regression. Dev Cell 17: 687-698. 
Mizoguchi I, Takahashi I, Nakamura M, Sasano Y, Sato S, Kagayama M, Mitani H (1996) An immunohistochemical study of regional differences in the distribution of type I and type II collagens in rat mandibular condylar cartilage. Arch Oral Biol 41: 863-869.

Morin PJ, Sparks AB, Korinek V, Barker N, Clevers H, Vogelstein B, Kinzler KW (1997) Activation of betacatenin-Tcf signaling in colon cancer by mutations in beta-catenin or APC. Science 275: 1787-1790.

Muzumdar MD, Tasic B, Miyamichi K, Li L, Luo L(2007) A global double-fluorescent Cre reporter mouse. Genesis 45: 593-605.

Neuhold LA, Killar L, Zhao W, Sung ML, Warner L, Kulik J, Turner J, Wu W, Billinghurst C, Meijers T, Poole AR, Babij P, DeGennaro LJ (2001) Postnatal expression in hyaline cartilage of constitutively active human collagenase-3 (MMP-13) induces osteoarthritis in mice. J Clin Invest 107: 35-44.

Premaraj S, Souza I, Premaraj T (2013) Focal adhesion kinase mediates $\beta$-catenin signaling in periodontal ligament cells. Biochem Biophys Res Commun 439: 487-492.

Rando C, Waldron T (2012) TMJ osteoarthritis: A new approach to diagnosis. Am J Phys Anthropol 148: 45-53.

Raymond M, Marchbank T, Moyer MP, Playford RJ, Sanderson IR, Kruidenier L (2012) IL-1 $\beta$ stimulation of CCD-18co myofibroblasts enhances repair of epithelial monolayers through Wnt-5a. Am J Physiol Gastrointest Liver Physiol 303: G1270-1278.

Reboul P, Pelletier JP, Tardif G, Cloutier JM, MartelPelletier J (1996) The new collagenase, collagenase-3, is expressed and synthesized by human chondrocytes but not by synoviocytes: A role in osteoarthritis. J Clin Invest 97: 2011-2019.

Roach HI, Yamada N, Cheung KS, Tilley S, Clarke NM, Oreffo RO, Kokubun S, Bronner F (2005) Association between the abnormal expression of matrix-degrading enzymes by human osteoarthritic chondrocytes and demethylation of specific $\mathrm{CpG}$ sites in the promoter regions. Arthritis Rheum 52: 3110-3124.

Robinson JA, Chatterjee-Kishore M, Yaworsky PJ, Cullen DM, Zhao W, Li C, Kharode Y, Sauter L, Babij P, Brown EL, Hill AA, Akhter MP, Johnson ML, Recker RR, Komm BS, Bex FJ (2006) Wnt/beta- catenin signaling is a normal physiological response to mechanical loading in bone. J Biol Chem 281: 31720-31728.

Scrivani SJ, Keith DA, Kaban LB (2008) Temporomandibular disorders. N Engl J Med 35: 26932705.

Sen B, Styner M, Xie Z, Case N, Rubin CT, Rubin J (2009) Mechanical loading regulates NFATc1 and betacatenin signaling through a GSK3beta control node. J Biol Chem 284: 34607-34617.

Shiomi T, Lemaître V, D’Armiento J, Okada Y (2010) Matrix metalloproteinases, a disintegrin and metalloproteinases, and a disintegrin and metalloproteinases with thrombospondin motifs in nonneoplastic diseases. Pathol Intä 60: 477-496.

Simon M, Grandage VL, Linch DC, Khwaja A(2005) Constitutive activation of the Wnt/beta-catenin signalling pathway in acute myeloid leukaemia. Oncogene 24: 24102420.

Singh M, Detamore MS (2008) Tensile properties of the mandibular condylar cartilage. J Biomech Eng 130: 11009-11017.

Stanton H, Rogerson FM, East CJ, Golub SB, Lawlor KE, Meeker CT, Little CB, Last K, Farmer PJ, Campbell IK, Fourie AM, Fosang AJ (2005) ADAMTS5 is the major aggrecanase in mouse cartilage in vivo and in vitro. Nature 434: 648-652.

Stickens D, Behonick DJ, Ortega N, Heyer B, Hartenstein B, Yu Y, Fosang AJ, Schorpp-Kistner M, Angel P, Werb Z (2004) Altered endochondral bone development in matrix metalloproteinase 13-deficient mice. Development 131: 5883-5895.

Wang M, Shen J, Jin H, Im HJ, Sandy J, Chen D (2011) Recent progress in understanding molecular mechanisms of cartilage degeneration during osteoarthritis. Ann N Y Acad Sci 240: 61-69.

Wang M, Tang D, Shu B, Wang B, Jin H, Hao S, Dresser KA, Shen J, Im HJ, Sampson ER, Rubery PT, Zuscik MJ, Schwarz EM, O'Keefe RJ, Wang Y, Chen D (2012) Conditional activation of $\beta$-catenin signaling leads to severe defects in intervertebral disc tissue. Arthritis Rheum 64: 2611-2623.

Wang M, Sampson ER, Jin H, Li J, Im H-J, Chen D (2013) MMP13 is a critical target gene during the progression of osteoarthritis. Arthritis Res Ther 15: R5.

Wang B, Jin H, Zhu M, Li J, Zhao L, Zhang Y, Tang D, Xiao G, Xing L, Boyce BF, Chen D (2014) Chondrocyte $\beta$-catenin signaling regulates postnatal bone remodeling through modulation of osteoclast formation in a murine model. Arthritis Rheumatol 66: 107-120.

Yang Y (2003) Wnts and Wing: Wnt signaling in vertebrate limb development and musculoskeletal morphogenesis. Birth Defects Res C 69: 305-317.

Zhang J, Jiao K, Zhang M, Zhou T, Liu X-D, Yu S-B, Lu L, Jing L, Yang T, Zhang Y, Chen D, Wang M-Q (2013) Occlusal effects on longitudinal bone alterations of the temporomandibular joint. J Dent Res 92: 253-259.

Zhu M, Chen M, Lichtler AC, O'Keefe RJ, Chen D (2008) Tamoxifen-inducible Cre-recombination in articular chondrocytes of adult Col2alCreER ${ }^{T 2}$ transgenic mice. Osteoarthritis Cartilage 16: 129-130.

Zhu M, Tang D, Wu Q, Hao S, Chen M, Xie C, Rosier RN, O'Keefe RJ, Zuscik M, Chen D (2009) Activation of $\beta$-catenin signaling in articular chondrocytes leads to osteoarthritis-like phenotype in adult $\beta$-catenin conditional activation mice. J Bone Miner Res 24: 12-21.

\section{Discussion with Reviewers}

Reviewer I: Can the authors provide an explanation on why they decided to use the Col2CreER mice and not the CollCreER mice, as they stated in the introduction that Col1 is more expressed in the superficial layer of the articular cartilage, the site first affected during the development of OA. Recent literature showed that beta catenin expression is very important for cartilage 
homeostasis in this layer of cells (Yasuhara et al., 2011); therefore, the effect of the overexpression of beta catenin in this location of the tissue might have a different effect. Authors: The reason that we used Col2-CreER ${ }^{\mathrm{T} 2}$ mice is because we found degenerative defects in articular cartilage and disc tissue in $\beta$-catenin(ex3 $)^{\text {Col2ER }}$ in which $\beta$-catenin expression was specifically targeted using the Col2-CreER ${ }^{\mathrm{T} 2}$ transgenic mice (Zhu et al., 2009; Wang et al., 2012). We agree with the reviewer that targeting $\beta$-catenin in the superficial layer using Coll-Cre or CollCreER mice is an important approach to determine the role of $\beta$-catenin in the superficial layer of TMJ cartilage. As a future direction, we plan to express $\beta$-catenin in Col1expressing cells in TMJ tissue and compare phenotypic difference between $\beta$-catenin (ex3) ${ }^{\text {Col2ER }}$ and $\beta$-catenin(ex3) COllER mice.

Reviewer II: Do the authors suppose that TMJ cartilage behaves more like hyaline or fibrocartilage, and why do they suppose the cartilages react in their presumed way? Authors: We have extracted RNA from TMJ tissues of $\beta$-catenin(ex3) ${ }^{\text {Col2ER }}$ mice and examined changes in gene expression in these tissues and found that expression of Runx2, Col10, Mmp13, Adamts4 and Adamts5 was significantly increased in TMJ tissues of $\beta$-catenin(ex3) ${ }_{C O I E R}$ mice compared to that of Cre-negative control mice.
Reviewer III: The authors could comment on why the surface of the joint remains smooth and is not eroded in $\beta$-catenin (ex3) Col2ER mice.

Authors: This is probably because we have used Col2CreERT2 mice targeting the middle and deep layers of TMJ cartilage but not the superficial layer. Coll is the major protein expressed in the superficial layer of TMJ cartilage.

Reviewer III: How is the claimed up-regulation of Adamts 5 and Mmp13 in $\beta$-catenin(ex3) Col2ER mice regulated by stabilised $\beta$-catenin?

Authors: We propose that overexpression of $\beta$-catenin in TMJ tissue causes up-regulation of Runx2, which subsequently promotes Mmp13 and Adamts 5 expression in $\beta$-catenin(ex3) Col2ER mice. This signalling mechanism was demonstrated in intervertebral disc tissues in our previous studies (Wang et al., 2012).

\section{Additional Reference}

Yasuhara R, Ohta Y, Yuasa T, Kondo N, Hoang T, Addya S, Fortina P, Pacifici M, Iwamoto M, Enomoto-Iwamoto M (2011) Roles of $\beta$-catenin signaling in phenotypic expression and proliferation of articular cartilage superficial zone cells. Lab Invest 91:1739-1752. 